\title{
ESTIMASI HERITABILITAS UDANG GALAH (Macrobrachium rosenbergii) BERBASISPADA KERAGAMAN FENOTIP
}

\author{
Lies Emmawati Hadie*), Wartono Hadie*), dan Sularto**) \\ *) Pusat Penelitian dan Pengembangan Perikanan Budidaya \\ Jl. Ragunan 20, Pasar Minggu, Jakarta Selatan 12540 \\ E-mail: ema_hadi@yahoo.com \\ **) Balai Penelitian Pemuliaan Ikan \\ Jl. Raya 2 Sukamandi, Subang 41256
}

(Naskah diterima: 28 Januari 2013; Disetujui publikasi: 26 Agustus 2013)

\begin{abstract}
ABSTRAK
Penelitian ini dirancang untuk menghitung heritabilitas pada sifat bobot udang galah (Macrobrachium rosenbergii) pada umur lima bulan. Lima full-sib dan 15 half-sib dipelihara pada dua tingkat salinitas yaitu $0 \%$ odan $10 \%$ dengan rata- rata bobot sebesar 5,6 g; dan $\sigma=0,40 \mathrm{~g}$. Komponen keragaman diestimasi dengan mixed model leastsquares dan maximum likelihood. Hasil penelitian menunjukkan bahwa respons genetik yang tinggi dapat diperoleh melalui seleksi bobot, karena nilai heritabilitas pada sifat tersebut relatif tinggi. Hasil penelitian ini juga memperlihatkan bahwa kisaran nilai $\mathrm{h}^{2}$ pada air tawar $(0,509-0,866)$ dan air payau $(0,235-0,499)$. Jadi nilai $h^{2}$ pada air tawar lebih tinggi dibandingkan dengan lingkungan air payau pada salinitas 10,0\% Kisaran nilai $h^{2}$ yang dicapai pada out-crossing antara koleksi Barito dengan Musi adalah 0,663 $\pm 0,037-0,866 \pm 0,047$. Implikasi dari hasil penelitian ini menunjukkan bahwa untuk menghasilkan perbaikan mutu genetik pada udang galah dapat ditempuh melalui program seleksi yang dikombinasikan dengan metode pemijahan secara out-crossing.
\end{abstract}

KATA KUNCI: udang galah, heritabilitas, mixed model least-squares, maximum likelihood

ABSTRACT: Estimating heritability of giant freshwater prawn (Macrobrachium rosenbergii) based on phenotype variance. By: Lies Emmawati Hadie, Wartono Hadie, and Sularto

This study was designed to estimate heritability for body weight of giant freshwater prawn (M. rosenbergii) at five months of age. Five full-sib and 15 half-sib families were reared under two different salinities namely $0 \%$ and $10.0 \%$ initial body weight of $5.6 \pm 0.40 \mathrm{~g}$. Variance components were estimated by a mixed model least-squares and maximum likelihood. The result suggested that a high amount of genetic response was obtained through selection for body weight. The value of $h^{2}$ in freshwater was higher than brackishwater (10\%d. These value are $(0.509-0.866)$ for freshwater and (0.235-0.499) for brackishwater respectively. Range of value for $h^{2} \pm$ SE obtain 0.663 $\pm 0.037-0.866 \pm 0.047$ there were out-crossing of Barito and Musi collection. Implication of this research indicated that they were improved genetic quality of giant freshwater prawn would be success through selection program that is combine with out-crossing of mating design.

KEYWORDS: giant freshwater prawn, heritability, mixed model leastsquares, maximum likelihood 


\section{PENDAHULUAN}

Parameter genetik yang mutlak diperlukan dalam aplikasi seleksi adalah adanya unsur heritabilitas pada setiap karakter yang akan diseleksi. Pengertian heritabilitas adalah mencakup bagian dari keragaman total yang diukur dengan ragam dari suatu sifat yang diakibatkan oleh pengaruh genetik. Nilai heritabilitas dapat diperhitungkan dalam dua kontek yaitu secara luas yang dipengaruhi oleh gen aditif, dominan, dan epistatik. Namun pengaruh genetik aditif umumnya lebih penting dari pengaruh genetik secara total. Dengan demikian dalam pemuliaan unsur heritabilitas yang digunakan adalah yang terkait dengan taksiran bagian aditif dari ragam keturunan dan dikenal sebagai heritabilitas dalam arti sempit dengan simbol $\mathrm{h}^{2}$ (Warwick et al., 1995). Heritabilitas suatu sifat sebenarnya merupakan rasio antara keragaman aditif $\left(V_{A}\right)$ dengan keragaman fenotip $\left(V_{p}\right)$. Menurut Tave (1986) dan Falconer \& Mackay (1996), heritabilitas itu menggambarkan persentase keragaman fenotip yang diprediksi akan diwariskan, karena heritabilitas adalah komponen genetik yang tidak dipisahkan sewaktu terjadi proses meiosis. Pemahaman mengenai nilai heritabilitas sangat penting dalam mengembangkan program seleksi yang bertujuan untuk memperbaiki mutu genetik hewan akuatik. Pemahaman itu dapat memberikan dasar untuk membuat prediksi besarnya kemajuan genetik yang dapat dicapai yang dinyatakan sebagai respons seleksi. Hal ini juga memungkinkan bagi para pemulia untuk membuat keputusan penting berkaitan dengan biaya yang harus dikeluarkan apakah akan sebanding dengan manfaat yang akan dicapai. Dalam teori heritabilitas, nilainya dapat berkisar antara 0 sampai 1,0 . Namun demikian nilai yang ekstrim ini jarang ditemukan pada sifatsifat kuantitatif pada hewan akuatik. Apabila suatu sifat mempunyai nilai heritabilitas nol, berarti sumber keragamannya sifat tersebut sepenuhnya berasal dari pengaruh lingkungan. Akan tetapi, sampai saat ini belum ada contoh suatu sifat pada hewan akuatik yang memiliki nilai heritabilitas nol. Beberapa sifat dengan heritabilitas relatif rendah dijumpai pada sifat- sifat reproduksi ikan, seperti heritabilitas ukuran, dan jumlah telur ikan rainbow dengan nilai 0,2 . Suatu fenotip dengan heritabilitas $8 \quad 0,25$ dapat efisien jika diaplikasikan dengan program seleksi, dan memberikan respons kemajuan genetik yang positif. Heritabilitas dengan nilai 70,15 tidak memberikan hasil yang efisien dalam mencapai kemajuan genetik. Sifat- sifat yang terkait dengan ukuran pada umumnya memiliki nilai heritabilitas yang tinggi yaitu rata- rata mencapai 80,30 . Sebagai contoh adalah heritabilitas bobot ikan channel catfish pada umur 120 hari mencapai 0,92 $\pm 0,095$ (Reagan, 1979). Beberapa penelitian menunjukkan bahwa pada lingkungan yang berbeda, maka nilai heritabilitas juga berbeda nilainya. Tave (1984) mendapati bahwa nilai heritabilitas sirip punggung pada ikan gupi mencapai 0,41 pada suhu $19^{\circ} \mathrm{C}$ dan pada suhu $25^{\circ} \mathrm{C}$ heritabilitasnya sebesar 0,77 . Hasil penelitian tersebut memperlihatkan bahwa estimasi heritabilitas harus dilakukan pada lingkungan yang sama dengan tempat di mana proses seleksi akan diaplikasikan. Sebagai contoh program seleksi pada ikan nila direncanakan akan dilaksanakan di kolam, maka estimasi nilai heritabilitas suatu sifat ikan tersebut harus dilakukan di kolam juga. Jika estimasi heritabilitas dilakukan pada bak, maka nilai yang didapatkan tidak akurat. Selain faktor lingkungan terdapat faktor lain yang dapat memengaruhi nilai heritabilitas pada sifat panjang dan bobot yaitu faktor umur (Tave \& Smitherman, 1980).

Menurut Kitcharoen et al. (2012), nilai heritabilitas udang galah akan meningkat sesuai dengan bertambahnya umur dan mencapai nilai sebesar 0,4 pada umur 23 minggu. Hal ini menunjukkan adanya indikasi bahwa terdapat potensi respons yang positif terhadap seleksi dalam sifat tertentu pada udang galah. Demikian pula menurut Gjedrem \& Baranski (2009), yang menyatakan bahwa selective breeding (pembiakan secara selektif) dalam akuakultur mempunyai potensi yang tinggi untuk peningkatan mutu genetik ikan dan udang. Dalam aplikasi pembiakan secara selektif aspek utama yang perlu mendapat perhatian adalah siklus reproduksi dari ikan yang dibudidayakan. Selain itu, diperlukan adanya dokumentasi terhadap peningkatan genetik pada setiap generasi. Hal ini termasuk catatan mengenai keuntungan ekonomi dari program pembiakan secara selektif.

Estimasi heritabilitas dapat dilakukan dengan beberapa metode yaitu realized her itability dan estimate heritability yang dilakukan berdasarkan keragaman fenotip dari sifat yang akan diamati. Estimasi diaplikasikan pada suatu populasi dan hanya berlaku pada populasi itu. Hal ini berkaitan dengan prediksi 
kemajuan genetik pada program pemuliaan, dan memungkinkan seorang pemulia membuat suatu keputusan penting mengenai biaya dan hasil yang akan dicapai. Oleh karena itu, estimasi heritabilitas menjadi aspek penting dalam program pemuliaan udang galah. Hal ini mengingat bahwa siklus hidup udang galah memerlukan habitat yang berada, yaitu di air payau pada fase larva dan di air tawar fase pembesaran. Oleh karena itu, potensi genetik udang galah pada kedua lingkungan perlu diketahui, agar potensi itu dapat dieksploitasi secara optimal.

Tujuan dari penelitian ini adalah mengetahui nilai heritabilitas pada populasi udang galah berbasis keragaman fenotip pada lingkungan air tawar dan air payau.

\section{BAHAN DAN METODE}

Koleksi udang galah yang digunakan dalam penelitian ini berasal dari Sungai Barito dan Sungai Musi. Udang yang telah dikoleksi kemudian diadaptasikan dengan lingkungan tambak pada salinitas $5 \%$ o $10 \%$ selama satu bulan. Desain pemijahan dilakukan dengan meto de out-crossing antara koleksi Barito x Musi (BM), dan inbreeding pada koleksi Barito x Barito (BB), sejumlah 5 full-sibs dan 15 half-sibs.

Pemeliharaan larva udang galah dilaksanakan dengan metode air jernih tanpa menggunakan plankton dengan salinitas 8,0\%o 12,0\%o(Alston \& Sampaio, 2000). Kepadatan larva yang digunakan adalah 100 ekor/ L. Pakan larva yang digunakan adalah nauplii Artemia dan pakan buatan dengan kadar protein 54,9\% yang diberikan sesuai dengan dosis yang dibutuhkan (D'Abramo \& New, 2000; Hadie \& Hadie, 2003). Komposisi pakan buatan larva udang galah seperti terlihat pada Tabel 1 .

Dosis pakan yang berupa nauplii Artemia dan pakan buatan untuk pemeliharaan larva udang galah dapat dilihat pada Tabel 2 .

Media larva dilengkapi dengan ther mostat heater untuk menjaga stabilitas suhu pada kisaran $28^{\circ} \mathrm{C}-31^{\circ} \mathrm{C}$. Pemeliharaan larva udang berlangsung selama 35 hari hingga mencapai pasca- larva (PL). PL selanjutnya diadaptasikan ke dalam air tawar secara bertahap dan selanjutnya dilakukan tahap pendederan PL (Correia et al., 2000).

PL yang dihasilkan kemudian diadaptasikan di lingkungan tambak. Selanjutnya udang galah dipelihara pada tambak dengan salinitas $0 \%$
Tabel 1. Komposisi dan analisis proksimat pakan buatan larva udang galah

Table 1. Composition and proximate analysis of artificial feed for giant prawn larval

\begin{tabular}{lc}
\hline $\begin{array}{c}\text { Bahan pakan } \\
\text { Feed ingredients }\end{array}$ & $\begin{array}{c}\text { Persentase } \\
\text { Percentage (\%) }\end{array}$ \\
\hline Cumi-cumi (Squid) & 27.6 \\
Udang (Shrimp) & 27.6 \\
Telur ikan (Fish eggs) & 6.9 \\
Telur ayam (Chicken eggs) & 6.9 \\
Minyak ikan (Fish oil) & 14.0 \\
Vitamin (Vitamin) & 1.0 \\
Garam (Salt) & 1.0 \\
Alginat (Alginate) & 15.0 \\
\hline \multicolumn{1}{c}{ Analisis proksimat } & Persentase \\
Proximate analysis & Percentage (\%) \\
\hline Protein (Protein) & 54.9 \\
Lemak (Fat) & 19.7 \\
Abu (Ash) & 7.7 \\
\hline
\end{tabular}

Sumber (Source): Hadie \& Hadie (1993)

dan $10 \%$ sesuai dengan perlakuan. Petakan tambak yang digunakan sebanyak 60 petak dengan luas masing- masing $5 \mathrm{~m} \times 10 \mathrm{~m}$. Padat penebaran pada setiap petak adalah 5 ekor/ $\mathrm{m}^{2}$. Ransum harian yang diberikan $10 \%$ bobot biomassa per hari pada bulan pertama, 5\%pada bulan kedua, dan 3\%pada bulan ketiga. Pakan yang digunakan adalah pelet udang komersial dengan kadar protein $30,0 \%$ lemak $5,0 \%$ serat kasar 4,0\% kadar abu 10,0\% dan kadar air $12,0 \%$

\section{Analisis Statistik dan Estimasi Keragaman Fenotip}

Keragaman dianalisis dengan mixed model least-squares dan maximum likelihood yang diimplementasikan dalam program software Harvey (1990). Analisis ini untuk mengevaluasi efek yang pasti memengaruhi bobot badan pada salinitas $0 \%$ odan $10 \%$, serta estimasi least squares means pada sifat bobot. Komponen keragaman diestimasi dengan prosedur maximum likelihood dalam software Harvey melalui model persamaan yang digunakan sebagai berikut (Santos et al., 2011): 
Tabel 2. Dosis pakan larva/ ekor/ hari selama pemeliharaan udang galah berlangsung Table 2. Dosage of feed larvae/individu/day-during larval rearing period the giant prawn

\begin{tabular}{lcc}
\hline $\begin{array}{c}\text { Hari ke- } \\
\text { Days of }\end{array}$ & $\begin{array}{c}\text { Jumlah nauplii Artemia } \\
\text { (ekor) } \\
\text { Number of nauplii } \\
\text { (tail) }\end{array}$ & $\begin{array}{c}\text { Brtemia } \\
\text { buatan kering } \\
\text { Weight of artificial } \\
\text { diets (mg) }\end{array}$ \\
\hline 3 & 5 & 0 \\
4 & 10 & 0 \\
$5-6$ & 15 & 0 \\
7 & 20 & 0 \\
8 & 25 & 0 \\
9 & 30 & 0 \\
$10-11$ & 35 & 0 \\
12 & 40 & 0 \\
$13-14$ & 45 & 70 \\
$15-24$ & 50 & $80-90$ \\
$25-30$ & 45 & $100-180$ \\
$30-p a n e n$ & 40 & 200 \\
30 until harvest PL & & \\
\hline
\end{tabular}

$$
Y=X \beta+Z a+W c+\varepsilon
$$

di mana:

$\mathrm{Y}$ ialah vektor pengamatan (bobot); $\mathrm{X}, \mathrm{Z}$, dan $\mathrm{W}$ adalah matriks insiden yang diketahui; $\beta$ adalah vektor efek lingkungan (salinitas); a, c, dan $\varepsilon$ adalah vektor dari genetik aditif, lingkungan maternal, dan efek random residu.

Asumsi normal dari efek random (a dan e) pada Persamaan 2:

$$
\left|\begin{array}{l}
y \\
a \\
e
\end{array}\right|-N\left[\left|\begin{array}{c||lll}
x B & V & Z G & R^{\prime} \\
0 & G Z^{\prime} & G & 0 \\
R & 0 & R
\end{array}\right|\right]
$$

di mana:

$\mathrm{V}=\operatorname{var}(\mathrm{y})=\mathrm{ZGZ}+\mathrm{R} ; \mathrm{G}$ adalah genetik (co) matriks keragaman, $\mathrm{G}=\mathrm{A} \sigma_{\mathrm{a}}^{2}$; dan $\mathrm{R}$ adalah residu dari (co) matriks keragaman, $R=I \sigma_{e}^{2}$ di mana: $A$ adalah genetik aditif berhubungan dengan matriks di antara seluruh udang pada dokumen kekerabatan

Nilai heritabilitas $\left(\mathrm{h}^{2}\right)$ diestimasi berdasarkan prinsip dari rumus menurut Falconer \& Mackay (1996):

$$
h^{2}=\frac{\sigma^{2}}{\sigma_{a}^{2}+\sigma_{e}^{2}}
$$

di mana:

$\mathrm{h}^{2}=$ Heritabilitas

$\sigma_{a}^{2}=$ Ragam aditif

$\sigma_{\mathrm{e}}^{2}=$ Ragam lingkungan

\section{HASIL DAN BAHASAN}

Hasil penelitian menunjukkan bahwa nilai heritabilitas udang galah yang diperoleh dari hasil estimasi berbeda pada lingkungan yang berbeda pula. Dalam hal ini udang galah yang dipelihara di lingkungan air tawar mempunyai nilai heritabilitas relatif lebih tinggi dibandingkan dengan nilai yang didapat pada lingkungan air payau bersalinitas $10 \%$ (Tabel 3).

Demikian pula estimasi heritabilitas berdasarkan maternal half-sibs rata- rata mencapai nilai yang lebih tinggi dibandingkan dengan full-sibs. Sebaliknya pada salinitas $10 \%$ nilai $\mathrm{h}^{2}$ pada maternal half-sibs lebih rendah daripada full-sibs. Hal ini terjadi pada udang galah hasil pemijahan koleksi Barito dengan Barito (BB), nilai heritabilitas berkisar antara 0,509-0,779 pada lingkungan air tawar dan $0,235-0,499$ pada lingkungan dengan salinitas $10 \%$ Hal ini kemungkinan terjadi karena habitat udang galah pada stadia dewasa adalah di air tawar, meskipun pada stadia larva udang galah hidup di air payau. Siklus hidup udang 
Tabel 3. Nilai heritabilitas \pm standar error $\left(h^{2} \pm \mathrm{SE}\right)$ dari karakter bobot udang galah yang dipelihara pada salinitas $0 \%$ odan $10 \%$ o

Table 3. Value of heritability \pm standard error $\left(h^{2} \pm S E\right)$ body weight character of giant prawn reared in the salinity of $0 \%$ and $10 \%$ o

\begin{tabular}{lccc}
\hline \multirow{2}{*}{$\begin{array}{c}\text { Sumber estimasi } \\
\text { Source of estimation }\end{array}$} & $\begin{array}{c}\text { Koleksi } \\
\text { Collection }\end{array}$ & \multicolumn{2}{c}{ Salinitas (Salinity) (\%) } \\
\cline { 3 - 5 } & & $\mathbf{0}$ & $\mathbf{1 0}$ \\
\hline $\mathrm{h}^{2} \pm \mathrm{SE}$ (Full sibs) & $\mathrm{BB}$ & $0.509 \pm 0.032$ & $0.499 \pm 0.319$ \\
$\mathrm{~h}^{2} \pm \mathrm{SE}$ (Maternal half sib) & BB & $0.779 \pm 0.044$ & $0.235 \pm 0.191$ \\
$\mathrm{~h}^{2} \pm \mathrm{SE}$ (Full sibs) & BM & $0.663 \pm 0.037$ & $0.491 \pm 0.032$ \\
$\mathrm{~h}^{2} \pm \mathrm{SE}$ (Maternal half sib) & BM & $0.866 \pm 0.047$ & $0.296 \pm 0.223$ \\
\hline
\end{tabular}

$\mathrm{BB}=$ Barito $\times$ Barito; $\mathrm{BM}=$ Barito $\times$ Musi

galah yang meliputi habitat air tawar dan payau memberikan efek yang signifikan terhadap keragaman genetik yang diekspresikan dalam bentuk nilai heritabilitas yang berbeda. Hasil yang diperoleh ini sesuai dengan Argue et al. (2002), Perez- Rostro \& Ibarra (2003), Kenway et al. (2006), dan Castillo- Jaurez et al. (2007) yang menyatakan bahwa lingkungan budidaya sangat berpengaruh terhadap estimasi parameter genetik pada krustasea. Hal ini berarti bahwa terdapat interaksi antara genotip dengan lingkungan pada suatu populasi. Dalam hal interaksi genotip- lingkungan diasumsikan terdapat beberapa kemungkinan kondisi. Dalam suatu kondisi tidak ada interaksi genotip- lingkungan, dalam kondisi lain didapati ada interaksi genotip- lingkungan yang kecil dan ada suatu kondisi adanya interaksi genotip- lingkungan yang nyata. Pada umumnya keragaan suatu sifat merupakan hasil dar interaksi antara genotip dengan lingkungan. Keragaan suatu sifat tergantung pada gen- gen yang dimiliki oleh suatu populasi, tetapi kondis lingkungan yang menunjang dibutuhkan untuk memberi kesempatan keragaan suatu sifat terekspos secara maksimal. Oleh karena itu asumsi yang dianut adalah bahwa interaksi genotip-lingkungan berlaku untuk suatu kondisi di mana reaksi genotip yang berbeda tidak sama pada lingkungan yang berbeda. Demikian pula yang terjadi pada populasi udang galah yang habitat aslinya adalah di air tawar, pada waktu udang itu dipelihara di lingkungan air payau, maka kondisi ini merupakan tekanan baginya. Tekanan lingkungan pada populasi udang galah tersebut mengakibatkan respons yang negatif yang mungkin terjadi karena adanya interaksi antara genotiplingkungan. Kondisi seperti itu rupanya me- mengaruhi ekspresi gen yang menguntungkan, sehingga heritabilitas di lingkungan air payau lebih kecil nilainya dibandingkan dengan heritabilitas udang galah di lingkungan air tawar terutama pada keragaan pertumbuhan bobot.

Nilai heritabilitas pada sifat bobot badan mencapai kisaran 0,50-0,86. Hal ini berarti bahwa udang galah termasuk memiliki kategori keragaman genetik yang moderat sampai tinggi. Kondisi ini memungkinkan dicapai perbaikan mutu genetik udang galah melalui program seleksi.

Dengan mempertimbangkan faktor desain pemijahan, ternyata udang galah koleksi Barito yang dipijahkan dengan koleksi Musi (BM) mempunyai nilai heritabilitas yang relatif lebih tinggi dibandingkan dengan koleksi Barito $x$ Barito (BB). Hasil yang diperoleh ini memberikan indikasi bahwa pemijahan secara silang luar (out-breeding) pada udang galah berdampak positif terhadap frekuensi gen dengan pengaruh aditif. Out-breeding yang dikombinasikan dengan seleksi massa sangat efektif dalam mengubah frekuensi gen yang mengakibatkan naiknya frekuensi gen yang menguntungkan (Warwick et al., 1995). Faktor positif dari out-breeding yaitu tidak adanya kecenderungan untuk fiksasi gen resesif yang tidak diinginkan dalam bentuk homosigot. Selain itu, juga akan mempertahankan frekuensi gen yang eksis bagi gen-gen dengan pengaruh netral. Jadi metode pemijahan secara out-breeding yang dikombinasikan dengan seleksi massa dapat diasumsikan sebagai suatu sistem yang diharapkan untuk menghasilkan kemajuan terus-menerus dengan risiko yang minimum. 
Hasil dari out-breeding memperlihatkan bahwa ukuran udang galah jantan umumnya lebih besar dibandingkan dengan udang betina pada umur yang sama. Hasil penelitian ini menunjukkan indikasi tersebut. Nilai least square \pm SE pada karakter bobot udang jantan adalah 19,79 $\pm 3,63\left(\mathrm{BM}_{1}\right)$ dan udang betina $16,1 \pm 3,63\left(\mathrm{BM}_{1}\right)$ seperti yang dapat dilihat pada Tabel 4 . Demikian pula udang hasil inbreeding memperlihatkan hasil yang sama yaitu seperti nilai least square $\pm \mathrm{SE}$ pada $\mathrm{BB}_{1}$ sebesar 22,51 $\pm 3,18$ untuk udang jantan dan $15,56 \pm 3,18\left(\mathrm{BB}_{1}\right)$ pada udang betina. Hasil secara lengkap dapat dilihat pada Tabel 4.

Dari Tabel 4, menunjukkan adanya dimorfisme seks pada pertumbuhan udang galah. Dalam hal ini udang jantan lebih cepat tumbuh dibandingkan dengan udang betina, karena perkembangan fisiologis yang cepat pada udang jantan, termasuk efisiensi pakan yang tinggi dan pemanfaatan pakan yang lebih baik. Moss \& Moss (2006) juga mendapatkan hasil yang serupa berkaitan dengan adanya dimorfisme seks pada pertumbuhan udang putih di manaudang betina tumbuh lebih cepat dibandingkan dengan udang jantan. Dari hasil penelitian ini dapat diperoleh fakta bahwa dalam pelaksanaan program seleksi udang galah perlu difokuskan pada udang jantan. Kondisi fisiologis udang jantan akan memberikan respons seleksi yang lebih optimal, sehingga perbaikan mutu genetik dapat dicapai dalam waktu yang lebih cepat.

Keragaan produktivitas udang galah yang meliputi fekunditas, sintasan, dan bobot pada akhir penelitian disajikan pada Tabel 5 .
Produktivitas udang galah terkait dengan bobot dan sintasan pada salinitas $0 \%$ omenunjukkan hasil yang lebih tinggi dibandingkan dengan pada salinitas $10 \%$ Sintasan udang mencapai $70,9 \% 77,0 \%$ dan bobot rata- rata 24,20- 25,7 g pada salinitas $0 \%$ q dan rata- rata bobot pada salinitas 10\%omencapai 19,3-22,1 g serta sintasan sebesar 39,2\% 40,0\%(Tabel 5). Hasil yang diperoleh ini memperlihatkan bahwa udang galah mempertahankan proses osmoregulasi dan harus mengalokasikan sejumlah energi untuk bertahan hidup di lingkungan air payau, sehingga pertumbuhan menjadi relatif lambat dibandingkan di air tawar. Hasil yang diperoleh ini sesuai dengan Bückle et al. (2006) yang menyatakan bahwa dalam osmoregulasi dibutuhkan sejumlah energi agar proses fisiologis itu dapat berlangsung secara optimal. Kondisi ini berpengaruh terhadap laju metabolisme udang yang dipelihara pada media yang tingkat salinitasnya lebih tinggi dari konsentrasi ion darahnya, maka energi untuk proses osmoregulasi akan cukup besar, dan akan lebih sedikit yang dapat digunakan untuk proses pertumbuhan. Proses osmoregulasi yang terjadi berhubungan dengan komposisi ion yang merupakan faktor penting dan memengaruhi sintasan dan pertumbuhan udang di perairan payau. Ion- ion tersebut yang memiliki peran besar dalam proses osmoregulasi, dalam hal ini adalah ion $\mathrm{Na}^{+}$dan $\mathrm{Cl}^{-}$(Davis et al., 2002). Menurut Fujaya (1999), bahwa osmoregulasi merupakan upaya mengontrol keseimbangan air dan ion- ion antara tubuh dan lingkungannya atau suatu proses pengaturan tekanan osmose. Hal ini penting dilakukan, terutama

Tabel 4. Nilai least square \pm SE pada karakter bobot udang galah koleksi Barito- Barito (BB) dan Barito- Musi (BM)

Table 4. Value of least square \pm SE for body weight character of giant prawn collected from Barito river (BB) and Barito x Musi (BM)

\begin{tabular}{ccc}
\hline \multirow{2}{*}{$\begin{array}{c}\text { Koleksi } \\
\text { Collection }\end{array}$} & \multicolumn{2}{c}{ Least square \pm SE } \\
\cline { 2 - 3 } & Jantan (Male) & Betina (Female) \\
\hline$B_{1}$ & $22.51 \pm 3.18$ & $15.56 \pm 3.18$ \\
$B_{2}$ & $27.36 \pm 5.51$ & $21.27 \pm 5.51$ \\
$B_{3}$ & $22.97 \pm 2.85$ & $15.71 \pm 2.85$ \\
$B_{3}$ & $19.79 \pm 3.63$ & $16.10 \pm 3.63$ \\
$B_{1}$ & $19.30 \pm 3.49$ & $15.96 \pm 3.49$ \\
$B_{2}$ & $28.31 \pm 3.76$ & $17.36 \pm 3.76$ \\
\hline
\end{tabular}

Notasi 1, 2, dan 3 = Ulangan pada setiap koleksi (Notation 1, 2, and $3=$ Replication of each collection 
D'Abramo, L.R. \& New, M.B. 2000. Nutrition, feeds and feeding. In: Freshwater prawn culture: the farming of Macrobrachium rosenbergii. New, M.B. \& Valenti, W.C. (Eds.), Blackwell Science, Oxford, England, p. 203- 220.

Davis, D.A., Saoud, I.P., McGraw, W.J., \& Rouse, D.B. 2002. Considerations for Litopenaeus vannamei reared in inland low salinity wa-

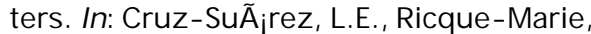
D., Tapia- Salazar, M., Gaxiola-CortÃ @s, M.G., Simoes, N. (Eds.). Avances en Nutrici $\tilde{A}^{3} n$ AcuÃ-cola VI. Memorias del VI Simposium Internacional de Nutrici $\tilde{A}^{3} n$ AcuÃ-cola. 3 al 6 de Septiembre del 2002. CancÃ on,

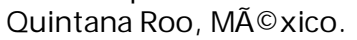

Falconer, D.S. \& Mackay, T.F.C. 1996. Introduction to Quantitative Genetics $4^{\text {th }}$ Ed. Longman, Harlow, England, 464 pp.

Fujaya, Y. 1999. Fisiologi lkan. Jurusan Perikanan Fakultas IImu Kelautan dan Perikanan Universitas Hasanudin. Ujung Pandang, 216 $\mathrm{hlm}$.

Gjedrem, G. \& Baranski, M. 2009. Selective breeding in Aquaculture: An Introduction. $1^{\text {st }}$ Edition. Springer. Aquacult. Res., 34: 543- 553.

Hadie, W. \& Hadie, L.E. 1993. Pembenihan udang galah skala rumah tangga. Penerbit Yayasan Kanisius. Yogyakarta, $110 \mathrm{hlm}$.

Hadie, W. \& Hadie, L.E. 2003. Budidaya Udang galah GIMacro di kolam, sawah tambak, dan tambak. PT Penebar Swadaya. Jakarta, 88 $\mathrm{hlm}$.

Harvey. 1990. Mixed Model Least Squares and Maximum Likelihood Computer Program. User's Guide for LSML, MW, and MIXMDL.

Kenway, M., Macbeth, M., Salmon, M., Benzie, J., Wilson, K., \& Knibb, W. 2006. Heritability and genetic correlations of growth and survival in black tiger prawn Penaeus monodon reared in tanks. Aquaculture, 259: 138- 145.

Kitcharoen, N., Rungsin, W., Koonawootrittriron,
S., \& Na- Nakorn, U. 2012. Heritability for growth traits in giant freshwater prawn, Macrobrachium rosenbergii (de Mann 1879) based on best linear unbiased prediction methodology. Aquaculture Research, 43: 19-25. doi: 10.1111/j.13652109.2011.02796.x

Moran, N.A. 1992. The evolutionary maintenance of alternative phenotypes. American Naturalist., 139: 971- 989.

Moss, D.R. \& Moss, S.M. 2006. Effects of gender and size on feet acquisition in the Pacific white shrimp Litopenaeus vannamei. J. World. Aqua. Soc., 37: 161- 167.

Perez- Rostro C.I. \&lbarra A.M. 2003. Heritabilities and genetic correlations of size traits at harvest size in sexually dimorphic $\mathrm{Pa}$ cific white shrimp (Litopenaeus vannamei) grown in two environments. Aquacult. Res., 34: 1- 7.

Reagan, R.E.Jr. 1979. Heritabilities and genetic correlation of desirable commercial traits in channel catfish. Res. Rep. Miss. Ag. For. Exp. Sta.

Santos, A.I., Riberio, R.P., Vangas, L., Mora, F., Filho, L.A., Fornari, D.C., \& de Oliviera, S.N. 2011. Bayesian Genetic Parameters for Body Weight and Survival of Nile Tilapia Farmed in Brazil. Pesq. Agropec. Bras. Brasilia, 46: 33- 43.

Tave, D. \& Smitherman, R.O. 1980. Predicted response to selection for early growth in Tilapia nilotica. Trans. Am. Fish. Soc., 109: 439- 445.

Tave, D. 1984. Genetics of dorsal fin ray number in the guppy, Poecilia reticulate. Copeia, p. $140-144$.

Tave, D. 1986. Genetics for Fish Hatchery Managers. AVI Publishing Company, Inc. Westport, Connecticut, p. 116- 165.

Warwick, E.J., Astuti, J.M., \& Hardjosubroto, W. 1995. Pemuliaan Ternak. Gadjah Mada University Press. Yogyakarta, hlm. 99- 138. 